\title{
Evaluating Parent Participation in Individualized Education Programs by Opinions of Parents and Teachers
}

\author{
Ş. Şenay İlik ${ }^{1}$, Rukiye Konuk $\mathrm{Er}^{1}$ \\ ${ }^{1}$ Necmettin Erbakan University, Ahmet Keleşoğlu Faculty of Education, Konya, Turkey \\ Correspondence: Ş. Şenay İlik, Necmettin Erbakan University, Ahmet Keleşoğlu Faculty of Education, Konya, Turkey.
}

Received: October 24, 2018

Accepted: December 25, 2018

Online Published: January 3, 2019

doi:10.11114/jets.v7i2.3936

URL: https://doi.org/10.11114/jets.v7i2.3936

\begin{abstract}
All individuals who are responsible for the education of learners with special needs must actively participate in Individualized Education Programs (IEP). Moreover, IEP is a common ground encouraging educators and parents to work together on an education plan. This study aims to evaluate the opinions of both parents and teachers regarding parent participation in IEP. The qualitative approach was used in this study. To profoundly examine the opinions of parents and special education teachers and to make them explain it in their own words, descriptive survey model, one of the qualitative research methods, was used. Descriptive survey model enables to organize data according to the themes put forward by the research questions and to present it by considering questions and dimensions. The purposive sampling method was used in this study to obtain more detailed information regarding the opinions of special education teachers and parents with children with special needs about the preparation and implementation process of IEP. 22 teachers and 25 parents participated in the study. Data were analyzed through content analysis. It was found that most of the parents do not know anything about IEP. It was also found that parents are not involved in the IEP process and they are not invited by the school/institution. As for the opinions of teachers, it was found that they have some problems about getting the parents to involve in the IEP process. It was seen that teachers are lack of knowledge regarding how to include parents in the IEP process.
\end{abstract}

Keywords: IEP, parents, teachers

\section{Introduction}

IEP has been the center of efforts to individualize the services pertain to learners around the world since the 1970s (Bagnato, Neisworth \& Munson, 1997; Bailey \& Wolery,1992; Davis, Kilgo \& Gamel, Mc Cormick, 1998; Espin, Deno \& Albayrak,1998; Siegel, 2017). In Turkey, preparing and implementing IEP for individuals with special needs became compulsory with the executive order no. 573 accepted in 1997 (Administration for Disabled People, 2008).

IEP is an extensive program enabling individuals to benefit from the educational activities prepared in line with the developmental characteristics, performance, and needs of learners with special needs. This program plans the support education these children will have and shows when, where, how long, and by whom this education will be provided. This program ensures the education rights of students with special needs (Ilik and Sarı, 2017; Regulation of Special Education Services, 2012). It is prepared with the cooperation of parents, special education teachers and other experts responsible for the education and development of the child. Parents are an important member of this process. Since the parents know their children better, they can give more accurate information regarding their children's strengths, needs and interests and the necessities for their children's education (Avcioğlu, 2011; Hunt, Goetz, \& Anderson,1986; Lynch \& Beare, 1990).

IEP is also an agreement on which the ones who provide and get the service come to terms. IEP, prepared by a team, requires the active participation of every individual who is responsible for the education of the children with special needs. Moreover, IEP is a common point which encourages parents and educators to work collaboratively on an education plan (Kargin, 2007; Reiman, Beck, Coppola, Engiles, 2010 ;The University of the State of New York, 2010). Parents are not only the first teachers of children in encouraging their children's positive personality traits and supporting their developmental areas, but they are also indispensable partners of educators (Crosbie- Burnet \& Klein, 2009).

Parents are the most significant member of the education process of children with special needs. The importance of 
parents in the education process is in the legal foundation of special education services. Although laws require parents to participate in the education process, it is stated in most studies that parents do not actively participate in this process. In their study Çimen, Öztürk and Eratay (2010) suggested that teachers do not receive support from parents while preparing IEP and teachers find parents uninterested. Avcioğlu (2011) in his study aiming to determine the opinions of teachers of mentally retarded students found that teachers have quite a few interviews with the parents, and the teachers do not sufficiently benefit from the opinions of parents and students. Moreover, Foley and Pang (2006) examined the opinions of principals of special education schools regarding IEP. They found that teachers working in special education schools must keep in touch with parents of students with special needs and thus, they must develop their cooperation skills. Researches must be done regarding how the parents participate in the process and what schools must do to make parents participate in this process (Keçeli and Kayısıl1, 2008).

Studies regarding to what extend IEP is implemented, the participation of parents to IEP preparation process, effects of IEP and efficiency of IEP have been found in the literature (Çimen Öztürk \& Eretay, 2010; Engiles, 2010; Hedeen, Peter, Moses \& Engiles, 2013; Jung, 2011; Reiman, Beck, Coppola, Kargın, 2007; Sanders, 2010;). This study aims to examine the opinions of parents and teachers regarding the parent participation in IEP. In order to reach this aim following questions are asked;

1) What are the opinions of parents regarding parent participation in the preparation, implementation and evaluation stages of IEP?

2) What are the opinions of teachers regarding parent participation in the preparation, implementation and evaluation stages of IEP?

\section{Method}

\subsection{Model of the Study}

This study was conducted through qualitative research method. To profoundly examine the opinions of parents and special education teachers and to make them explain it in their own words, descriptive survey model, one of the qualitative research methods, was used. Descriptive survey model enables to organize data according to the themes put forward by the research questions and to present it by considering questions and dimensions (Hesse-Biber ve Leavy, 2011).

\subsection{Study Group}

The purposive sampling method was used in this study to obtain more detailed information regarding the opinions of special education teachers and parents with children with special needs about the preparation and implementation process of IEP. Criterions were determined to choose parents for purposive sampling (Yıldırım, \& Şimşek, 2005). The criterions for choosing teacher were working in private special education schools or state schools in central districts of Konya and volunteering to participate in the study. Evaluating Parent Participation in Individualized Education Programs by Opinions of Parents and Teachers. Volunteering to participate in the study, and having a child with special needs who is still having special education are the criterions for choosing parents.

22 teachers working in the central districts of Konya and 25 parents participated in the study. The demographic characteristics of teachers and parents are shown in Table 1 and Table 2.

Table 1. Demographic Characteristics of Teachers

\begin{tabular}{|c|c|c|c|c|c|c|}
\hline \multicolumn{7}{|c|}{ Work Experince } \\
\hline & \multicolumn{2}{|c|}{ Male } & \multicolumn{2}{|c|}{ Female } & \multicolumn{2}{|c|}{ Total } \\
\hline & $\mathrm{f}$ & $\%$ & $\mathrm{f}$ & $\%$ & $\mathrm{f}$ & $\%$ \\
\hline $0-5$ & 2 & 9.09 & 5 & 22.7 & 7 & 31.9 \\
\hline $6-10$ & 4 & 18.1 & 7 & 31.8 & 11 & 50 \\
\hline $11-15$ & 1 & 4.5 & 3 & 13.6 & 4 & 18.1 \\
\hline Total & 7 & 31.8 & 15 & 68.1 & 22 & 100 \\
\hline
\end{tabular}

As seen in Table 1 there are 7 male and 15 female participants. Although teachers have different work experience, the number of teachers 6-10 years of work experience is higher than others. 
Table 2. Demographic Characteristics of Parents

\begin{tabular}{lllllll}
\hline Age & Mother & \multicolumn{3}{c}{ Total } \\
& $\mathrm{f}$ & $\%$ & $\mathrm{f}$ & $\%$ & $\mathrm{f}$ & $\%$ \\
\hline $20-30$ & 9 & 36 & 2 & 8 & 11 & 44 \\
$31-40$ & 5 & 20 & 0 & 0 & 5 & 20 \\
$41-55$ & 8 & 32 & 1 & 4 & 9 & 36 \\
Total & 22 & 88 & 3 & 12 & 25 & 100
\end{tabular}

As seen in Table 2, 22 of the participants are a mother and 3 of them are a father. It is seen that mothers participated in the study more than fathers and most of the participants are between 20-30 year old.

\section{Semi-Structured Interview Technique}

Data were collected through semi-structured interview technique. In the process of developing the interview form, a draft form was prepared by examining the studies conducted before. To ensure the internal validity of the interview form, opinions of experts were received and the form is revised accordingly. The items revised by the experts were used in the pilot study. The pilot study form was implemented on three teachers and three parents, and ambiguous sentences were corrected according to the opinions of them. The forms were finalized and made ready to be used in the study.

\subsection{Data Collection}

The purpose of the study and how it would be implemented were clearly expressed in the interviews. Moreover, it is emphasized that participants were kept anonymous. Interviews were recorded and notes were taken at the same time. Interviews lasted 20-25 minutes.

\subsection{Data Analysis and Comments}

Obtained data were analyzed through content analysis. The content analysis aims to organize similarities in the data by creating themes and concepts, and to interpret meaning from those. For this purpose, firstly obtained data were conceptualized, secondly arranged rationally according to those concepts and finally the themes explaining the data were determined (Tavşancıl \& Arslan, 2001; Yıldırım \& Şimşek, 2005). Furthermore, some of the opinions of teachers and parents were given without any change.

\section{Findings}

The findings are presented according to aims.

\subsection{Evaluating Parent Participation in Individualized Education Programs by Opinions of Parents}

Table 3. Opinions of Parents Regarding the Question "what is IEP?"

\begin{tabular}{llr}
\hline Opinions & f & \% \\
\hline A program helping to follow development of the students & 6 & 24 \\
I do not know & 19 & 76 \\
Total & $\mathbf{2 5}$ & $\mathbf{1 0 0}$
\end{tabular}

More than half the parents (76\%) do not know what the IEP is and these parents mistake IEP for diagnostic reports. Some of the parents explained what the IEP is. This shows that parents are insufficiently informed about IEP. The opinions reflecting this situation are given below:

'IEP shows my students' development. The subjects my student receive are determined with it.' (P.22)

'I don't know what it means exactly, but I think it is a document sent by the school for me to sign.' (P.13)

Table 4. Opinions of Parents Regarding the Question 'Were you invited to the school in the preparation stage of IEP?'

\begin{tabular}{llr}
\hline Opinions & F & \% \\
\hline I was invited & 3 & 12 \\
I was not invited & 22 & 88 \\
Total & $\mathbf{2 5}$ & $\mathbf{1 0 0}$ \\
\hline
\end{tabular}


Almost all the parents said 'no' to the question 'were you invited to the school in the preparation stage of IEP?' Only three of the participants stated that they were invited once a year.

'I was neither invited to school nor informed about such a program. Institution occasionally invites me to sign some documents. I visit school voluntarily.' (P.16)

'I so lucky in this because our teacher gets my opinions about the subjects he is going to teach. Although I am not knowledgeable about special education, our teacher wants to decide together. (P.18)

Table 5. Opinions of Parents Regarding the Question "Do you think the goals defined for your child meet his needs?"

\begin{tabular}{llc}
\hline Opinions & f & \% \\
\hline I don't think so & 20 & 80 \\
I think so & 5 & 20 \\
Total & $\mathbf{2 5}$ & $\mathbf{1 0 0}$
\end{tabular}

Most of the parents say that the goals of IEP defined for their children don't meet his/her needs (80\%). Some of the parents think that the goals are defined according to their children's needs $(20 \%)$. Some of the opinions about this question are given below.

'It didn't meet my child's needs because I know my child and he has more problems in social relations. But his teacher focuses on reading and writing.' (P.12)

'It meets my child's needs. My child has improved a lot since he started to receive education at this institution.' (P.3)

Table 6. Opinions of Parents Regarding the Question "Did you make any efforts to participate in IEP?"

\begin{tabular}{llr}
\hline Opinions & $\mathrm{f}$ & $\%$ \\
\hline Yes & $\mathbf{2 0}$ & $\mathbf{8 0}$ \\
No & $\mathbf{5}$ & $\mathbf{2 0}$ \\
Total & $\mathbf{2 5}$ & $\mathbf{1 0 0}$
\end{tabular}

The opinions of parents regarding "Did you make any efforts to participate in IEP?" varies. While some of the parents state that they make an effort to participate in IEP preparation process because they want to state their opinions about their child's needs, others express that they don't make any efforts. Opinions of parents regarding this question are given below.

'I want to talk about what I think about my child. I talk to teachers one to one but they don't care about what I say.' (P.12)

'I don't make any efforts because I think it is unsuitable to interfere. Teachers know better.' (P.6)

Table 7. Opinions of Parents Regarding the Question "Do you evaluate the achievement of your child with the teacher at the end of the education year?"

\begin{tabular}{llr}
\hline Opinions & $\mathrm{f}$ & $\%$ \\
\hline Yes & $\mathbf{1 0}$ & $\mathbf{4 0}$ \\
No & $\mathbf{1 5}$ & $\mathbf{6 0}$ \\
Total & $\mathbf{2 5}$ & $\mathbf{1 0 0}$
\end{tabular}

Most of the parents (60\%) stated that they didn't evaluate the end of year achievement of their child with the teacher, but they also stated that teachers sent them an evaluation report at the end of the year. Some of the opinions of parents reflecting this result are given below.

'I wasn't invited to the school in the education process of my child. Teachers sent evaluation reports at home.'(P.3)

My child has autism so we need a lot of things. Thank god our teachers are so understanding in this. We meet both at the beginning and at the end of the year. (P.8)

3.2 Evaluating Parent Participation in Individualized Education Programs by Opinions of Teachers 
Table 8. Opinions of Teachers Regarding the Question "Why Do You Prepare Individualized Education Programs?"

\begin{tabular}{lrr}
\hline Opinions & $\mathrm{f}$ & $\%$ \\
\hline $\begin{array}{l}\text { To support academic achievement and ability development of learners with special } \\
\text { needs }\end{array}$ & 5 \\
$\begin{array}{l}\text { Because students have individual differences, different disability types, different } \\
\text { learning levels and different developmental characteristics }\end{array}$ & 123 \\
To plan the education given to the students & 5 & 54 \\
Total & $\mathbf{2 2}$ & $\mathbf{1 0 0}$ \\
\hline
\end{tabular}

$23 \%$ of the teachers stated that they prepare individualized education programs to support academic achievement and ability development of learners with special needs. $54 \%$ of the teachers expressed that they prepare IEP because students have individual differences, different disability types, different learning levels, and different developmental characteristics. Another $23 \%$ of the teachers said they prepare IEP to give a planned education to the students. Some of the opinions of teachers about this question are given below.

'We teach the subjects and abilities to a student with special needs must learn by following a program. Thus, students can keep up with their peers in academic achievement and ability development areas. (T.5)

'In order to meet the needs of students with special needs, we must provide the best educational environment. (T.22)

'IEP is prepared for each student because the needs and requirements of every student are different. (T.16)

Table 9. Opinions of Teachers Regarding the Question "Do You Receive Help from Parents While Preparing IEP?"

\begin{tabular}{lcc}
\hline Opinions & $\mathrm{f}$ & $\%$ \\
\hline We partially receive help & 2 & 13.3 \\
We don't receive any help & 11 & 50 \\
We only receive help while filling rough evaluation form & 9 & 36.7 \\
Total & 22 & 100
\end{tabular}

The opinions of teachers regarding receiving help from parents while preparing IEP are as follows. $13.3 \%$ stated that they partially receive help from parents. 50\% expressed that they don't receive any help from parents while preparing IEP. $36.7 \%$ of teachers said that they only receive help while filling in the rough evaluation form. Opinions of teachers reflecting these results are given below.

'We only receive help while filling in the rough evaluation form.'(T.8)

'We don't receive any help while preparing IEP. We prepare it by considering the previous development of the child.' (T.9)

'We partially receive help' (T.1)

Table 10. Opinions of Teachers Regarding the Question "Do you think the parents need to participate in the preparation and implementation stages of IEP?

\begin{tabular}{lll}
\hline Opinions & $\mathbf{f}$ & $\mathbf{\%}$ \\
\hline Parents need to participate in all the stages of IEP & 9 & 41 \\
They don't need to participate in & 8 & 36.3 \\
They need to partially participate in & 5 & 22.7 \\
Total & $\mathbf{2 2}$ & $\mathbf{1 0 0}$ \\
\hline
\end{tabular}

As seen in Table 10, while $41 \%$ of the teachers stated parents must participate in the process, $36.3 \%$ of them asserted that parents do not need to participate in the process and $22.7 \%$ of the teachers expressed that parents need to partially participate in the preparation and implementation processes of IEP. Some of the opinions of teachers are given below.

'We can achieve nothing by working on our own. Parent-teacher collaboration brings success. '(T.13)

'Parents want their children to have the abilities their peers have. They don't take into consideration the needs of their children. This hinders the children to achieve their basic needs. (T.9)

'Yes. Following questions can only be answered by parents: What do they expect from their children? Which abilities and knowledge do their children need?'(T.6) 
Table 11. Opinions of Teachers Regarding the Question "What Kind of difficulties do you have in parent participation while preparing IEP?"

\begin{tabular}{lll}
\hline Opinions & f & $\mathbf{\%}$ \\
\hline Parents impose the information they find from internet. & 9 & 40.1 \\
The expectations of parents do not match with the child's condition & 4 & 19.8 \\
Indifferent parents. & 9 & 40.1 \\
Total & $\mathbf{2 2}$ & $\mathbf{1 0 0}$ \\
\hline
\end{tabular}

The opinions of teachers regarding the question "what kind of difficulties they have in parent participation while preparing IEP?" fall into three categories. $40.1 \%$ of the teachers stated that parents want to impose what they find on the internet. Another $40.1 \%$ expressed that the parents are so indifferent and the remaining $19.8 \%$ thought that the expectation of parents does not match with the child's condition. Some of the opinions of teachers regarding this question are given below.

'Unfortunately, the information pollution which is the problem of this era shows itself in our field. Parents learn erroneous and sometimes irrelevant information on the internet and want us to implement them as if they knew better. We can explain it to some parents but others don't listen. So the students are affected by this.'(T.14)

'We have difficulty because parents think that their children have a mild mental retardation. They believe that their children can learn reading-writing and can be independent soon. They cannot be objective about this.' (T.7)

'There are some parents who are impossible to include the IEP process because they are so indifferent that let alone participating in IEP, they couldn't meet the basic needs of their child.' (T.10)

\section{Discussion}

When the necessity of collaboration of parents and teachers are taken into consideration (Karasu \& Mutlu, 2014; Y1ld1z \& Melekoğlu, 2016), this process advances more productive and faster for the children with special needs (Aytekin \& Bayhan, 2015). There are some difficulties in making parents collaborate while they are in the process of accepting having a child with different developmental characteristics. Thus, following elements hinder parent participation; parents deny the present situation and blame themselves, they ignore their knowledge and abilities, they are indifferent to religious beliefs and cultural diversities, and they do not make any effort to have the necessary education and information (Jung, 2011; Simon, 2006). When the services provided on this subject are considered, special education teachers are responsible for making parents actively participate in the process and providing them with the support they need.

Since the parents are primary caretakers of the children with special needs, they have to participate in the IEP process. However, as it can be understood from the results, parents need to be informed and guided. Accordingly, Avcioğlu (2011) found in his study that parents do not have sufficient information about IEP preparation, implementation and evaluation processes and that they almost never participate in these processes. Many factors such as sensitivity in emotional conditions, the delays in reaching the professional support or in guidance, and the negative attitudes they exposed could negatively affect the participation in IEP. One of the important results of the study is that the parents behave timidly about participating in the IEP process. Thus, parents need to feel comfortable to take an active role in this process (Reiman, Beck, Coppola \& Engiles, 2010). When things to be done are discussed in the IEP implementation meeting, the subjects increasing parent participation must be emphasized. For instance, the subjects such as emphasizing that they are the best information source for their children, using a clear and understandable language that they can understand, encouraging them for participation, and explaining the importance of collaboration must be emphasized (Hedeen, Peter, Moses \& Engiles, 2013). On the other hand, results revealed that some of the teachers didn't consider the parent participation in every stage of IEP necessary. This result shows that teachers also need to be informed about the necessity and importance of parent support. Many studies (Akalın, 2014; Eason \& Whitbread, 2006; Kale, Dikici Sığırtmaç, Nur \& Abbak, 2016; Karasu \& Mutlu, 2014) suggested that both the special education teachers and teachers from other branches preparing IEP have difficulties in communicating with parents because of different reasons such as insufficient knowledge. İlik (2015) stated that the problems encountered in IEP were caused by the inadequate knowledge of parents. The study suggested a program to make parents participate in the IEP process. In his study Vuran (2005) revealed that parents were an indispensable element in IEP, but that they didn't participate in the process. Thompson (2010) suggested that the majority of the problems teachers had during IEP preparation process were resulted from parents. However, parents have private information about their children and this information is of great importance while preparing IEP. Likewise, the opinions and experiences of teachers about the children may contain some information that parents do not know. So, parents get the chance of knowing their children better thanks to the information provided by 
the children. Parents can take an active role in encouraging their children and in linking the information taught in school to the opportunities they can find outside (Keçeli \& Kays1l1, 2008). It should not be forgotten that parents are the first teachers of their children and they are the most accurate source of information about their children. The teachers realizing this fact experience a more successful education process. On the contrary, evaluating a child with special needs with certain abilities in a limited time and environment causes the teachers to move away from realistic goals. Boavida, Aguiar, McWilliam \& Pimentel (2010) conducted a study to examine the quality of IEP prepared for children with disabilities in early childhood. They found that since the aims of IEP are defined to cover a wide range of area, they are far from being natural, functional and measurable. Moreover, they emphasized the teacher training to improve the effectiveness of IEP.

In the present study teachers criticized the lack of parent participation, besides, they stated that parent participation may negatively affect the IEP process. The conflict between the opinions of teachers is striking. Another striking point is that there is a conflict between the parents' opinions about what the IEP is and what it aims and their negative opinions about not being invited to the school for IEP. Based on these results following suggestions can be made;

1. Teachers need to be informed about the parent participation in the IEP process.

2. Parents need to be informed about participating in the IEP process

3. Educational activities which bring teachers and parents together must be organized.

\section{References}

Avcioglu, H. (2011). Mental Handicapped Class Teachers' Thoughts on Preparing IEP (Individualized Education Program), Ankara University Faculty of Educational Sciences Journal of Special Education, 12(1), 39-53.

Aytekin, C, Bayhan, P . (2015). Early Intervention Steps, Hacettepe University Faculty of Health Sciences Journal, 2(2), 1-14. Retrieved from http://dergipark.gov.tr/husbfd/issue/7895/103942

Bagnato, S. J., Neisworth, J. T., \& Munson, S. M. (1997). LINKing assessment and early intervention: An authentic curriculum-based approach. Baltimore, MD, US: Paul H Brookes Publishing.

Bailey, D. B., \& Wolery, M. (1992). Teaching infants and preschoolers with disabilities (2nd ed.). Upper Saddle River, NJ: Prentice Hall.

Boavida, T., Aguiar, C., McWilliam, R. A., \& Pimentel, J. S. (2010). Quality of Individualized Education Program Goals of Preschoolers With Disabilities, Infant \& Young Children, 23(3), 233-243. https://doi.org/10.1097/IYC.0b013e3181e45925

Cimen Oztürk, C., \& Eretay, E. (2010). Determining Opinions of Teachers of Students with Mental Retardation Attending an Education Application School on The Individualized Education Program, Abant Izzet Baysal University Journal of Faculty of Education, 10(2), 145-159.

Crosbie-Burnet, M., \& Klein, D. M. (2009). The Fascinating Story of Family Theories. The WileyBlackwell Handbook of Faimily Psychology. Blackwell Publishing Ltd. https://doi.org/10.1002/9781444310238.ch3

Davis, M. D., Kilgo, J. L., \& Gamel-McCormick, M. (1998). Young children with special needs. Needham Heights, MA: Viacom

Eason, A. I., \& Whitbread, K. (2006). IEP and Inclusion TIPS for Parents and Teacher, Edt: Tom Kinney, Attainment Company, Printed in the United States of America.

Espin, C. A., Deno, S. L., \& Albayrak-Kaymak, D. (1998). Individualized education programs in resource and inclusive settings: How "individualized" are they? Journal of Special Education, 32, 164-174. https://doi.org/10.1177/002246699803200303

Foley, R. M., \& Pang, L. S. (2006). Alternative Education Programs: Program and Student Characteristics, The High School Journal. pp:10-21. https://doi.org/10.1353/hsj.2006.0003

Hedeen, T., Peter, M., Moses, P., \& Engiles, A. (2013). Individualized Education Program(IEP)/Individualized Family Service Plan (IFSP) Facilitation: Practical Insights and Programmatic Considerations, Published by Center for Appropriate Dispute Resolution in Special Education (CADRE).

Hesse-Biber, S. N., \& Leavy, P. H. N. S. (2011). The practice of qualitative research (2nd ed.). USA: Sage Publications, Inc.

Hunt, P., Goetz, L., \& Anderson, J. (1986). The Quality of IEP Objectives Associated with Placement on Integrated versus Segregated School Sites, Journal of the Association for Persons with Severe Handicaps, 11(2), 125-130. https://doi.org/10.1177/154079698601100206 
Ilik, Ş. Ş. (2015) The effect of individualized education program training on teachers' qualifications for IEP, Doctoral Dissertation Necmettin Erbakan University, Department of Educational Sciences, Konya, Turkey.

Ilik, Ş. Ş., \& Sarı, H. (2017). The training program for individualized education programs (IEPs): Its effect on how inclusive education teachers perceive their competencies in devising IEPs. Educational Sciences: Theory \& Practice, 17, 1547-1572. https://doi.org/10.12738/estp.2017.5.0424

Jung, A. W. (2011). Individualized Education Programs (IEPs) and Barriers for Parents from Culturally and Linguistically Diverse Backgrounds, Diversity and Special Education, Spring 2011.

Kale, M., Dikici Sigırtmac, A., Nur, İ., \& Abbak, B. (2016). Investigating Pre-school Teachers' Opinions about Inclusive Education Applications, International Journal of Early Childhood Education Studies, 1(2), 35-45. Retrieved from http://dergipark.gov.tr/ijeces/issue/22946/355278

Karasu, T., \& Mutlu, Y. (2014). The Problems Existıng at Special Education and Bring Forward Solution Proposals from the View of Teachers: The Sample of Muş, Journal of Social Sciences of Mus Alparslan University, 2(1), 47-66.

Kargin, T. (2007). The Process for Educational Assessment and Individualized Education Programme, Ankara University Faculty of Educational Sciences Journal of Special Education, 8(1), 1-13.

Keceli Kaysil1, B. (2008). Parent Involvement To Improve Academic Achievement, Ankara University Faculty of Educational Sciences Journal of Special Education, 9(1), 69-83.

Pacer Center (2018). A Guide to the Individualized education Program (IEP) for Minnesota Parents, https://www.pacer.org/parent/php/PHP-a12.pdf

Parent's Guide to Special Education (2010). Virginia Department of Education Division of Special Education and Student Services, http://www.doe.virginia.gov/special_ed/parents/parents_guide.pdf

Reiman, J. W., Beck, L., Coppola, T., \& Engiles, A. (2010). Parents' experiences with the IEP process: Considerations for improving practice. Published by Center for Appropriate Dispute Resolution in Special Education (CADRE). https://files.eric.ed.gov/fulltext/ED512611.pdf

Sanders, M. R. (2010). A Comparative Investigation of Parent and Student. Attendance at IEP / Transition Meetings for Students with Disabilities. (Doctoral Dissertation, Texas Woman's University, (2010), 115, ATT34 14427

Simon, J. B. (2006). Perceptions of the IEP requirement. Teacher Education and Special Education, 29(4), 17-27. https://doi.org/10.1177/088840640602900403

Tavsanc1l, E., \& Aslan, E. (2001). Content analysis and sample practices for verbal, written and other materials, İstanbul: Epsilon Publications.

Thompson, A. (2010). Barriers to individualized education planning in the Appalachian of Ohio. Unpublished masteres thesis. Ohio Üniversitesi, Ohio.

Vuran, S. (2005). Bireyselleştirilmiş eğitim programları (BEP). O. Gürsel. (Ed.), Bireyselleştirilmiş eğitim programlarının geliş̧tirilmesi, Eskişehir: Anadolu Üniversitesi Açık öğretim Fakültesi Yayınları.

Yıldırım, A., \& Şimşek, H. (2005). Sosyal bilimlerde nitel araştırma yöntemleri. Ankara: Seçkin

Yıldız, N. G., \& Melekoglu, M. A. (2016). Evaluating Views of Teacher Candidates from Intellectual Disabilities Program towards Inclusion and Enrolled Teacher Training Program. Journal of Theoretical Educational Science, 9(2), 310-325. https://doi.org/10.5578/keg.5858

\section{Copyrights}

Copyright for this article is retained by the author(s), with first publication rights granted to the journal.

This is an open-access article distributed under the terms and conditions of the Creative Commons Attribution license which permits unrestricted use, distribution, and reproduction in any medium, provided the original work is properly cited. 